\title{
ENSO Influences on Rainfall Extremes around Sulawesi and Maluku Islands in the Eastern Indonesian Maritime Continent
}

\author{
Sopia Lestari ${ }^{1}$, Jun-Ichi Hamada ${ }^{2}$, Fadli Syamsudin ${ }^{1}$, Sunaryo ${ }^{3}$, Jun Matsumoto ${ }^{2,4}$, and Manabu D. Yamanaka ${ }^{4,5}$ \\ ${ }^{1}$ Agency for the Assessment and Application of Technology, Jakarta, Indonesia \\ ${ }^{2}$ Graduate School of Urban Environmental Sciences, Tokyo Metropolitan University, Hachioji, Japan \\ ${ }^{3}$ Agency for Meteorology Climatology and Geophysics, Jakarta, Indonesia \\ ${ }^{4}$ Japan Agency for Marine-Earth Science and Technology, Yokosuka, Japan \\ ${ }^{5}$ Graduate School of Science, Kobe University, Kobe, Japan
}

\begin{abstract}
El Niño Southern Oscillation (ENSO) influences on rainfall extremes around Sulawesi and the Maluku Islands in the eastern Indonesian Maritime Continent were investigated focusing on spatial and seasonal aspects using daily rainfall data at 23 stations during 1972-2012. The results show that interannual variations in rainfall extremes were strongly correlated with the ENSO phases. Wetter (drier) conditions were associated with La Niña (El Niño) events, in terms of total precipitation, rainy days, and consecutive dry days at more than $90 \%$ of the stations. Dry days tend to increase more than 2 months in the El Niño than La Niña years causing severe droughts in the region. Frequency and number of stations of heavy rainfalls increased (decreased) during La Niña (El Niño) events, whereas ENSO influences were weak (strong) on severest (moderately intense) rainfall events. ENSO influences on rainfall amount and number of rainy days vary spatially and seasonally. They were predominant during July-November but less during December-February. Heavy rainfall frequency was significantly higher during La Niña than El Niño years in transitional seasons.
\end{abstract}

(Citation: Lestari, S., J.-I. Hamada, F. Syamsudin, Sunaryo, J. Matsumoto, and M. D. Yamanaka, 2016: ENSO influences on rainfall extremes around Sulawesi and Maluku Islands in the Eastern Indonesian maritime continent. SOLA, 12, 37-41, doi:10.2151/ sola.2016-008.)

\section{Introduction}

The Indonesian Maritime Continent (IMC) is one of the hot spots where a few hundred millions people are susceptible to the immense impact of climate change in terms of water resources and natural disasters. The occurences of rainfall extreme events have drawn much attention recently, because of their pronounced influences on economical sustainability and societal developments (Easterling et al. 2000; Alexander et al. 2006). Most previous studies revealed an increase in frequency of heavy rainfall events over a large area of the globe including Southeast Asian monsoon region in recent decades using long-term daily rainfall dataset (Frich et al. 2002; Alexander et al. 2006; Endo et al. 2009). Recently, Villafuerte and Matsumoto (2015) examined trends of heavy rainfall in the Southeast Asian monsoon region and their links with ENSO during 1951-2007 using gauge-based gridded rainfall dataset (APHRODITE, Yatagai et al. 2012). Decreasing trends are significant in most parts of the IMC, but increasing trend is also found in the eastern IMC. Thus, it will be important to explore the regional characteristics of rainfall extremes over the IMC.

Generally, convective activity in the IMC is more active

Corresponding author: Sopia Lestari, Agency for the Assessment and Application of Technology, Jl. M.H. Thamrin No. 8, Jakarta Pusat, 10340, Indonesia. Email: sopia.lestari@bppt.go.id. C2016, the Meteorological Society of Japan. than in other tropical regions because of its abundant moistures supplied from the tropical western Pacific Ocean warm pool and Indian Ocean (Ramage 1968; Mori et al. 2004). The local and regional characteristics of the islands cause the different seasonal convective activity due to the interaction between monsoonal wind and complex topography (Hamada et al. 2002; Aldrian and Susanto 2003; Chang et al. 2005). The western IMC is characterized as "wetter" and the boreal winter rainy season (e.g., Sumatera and Jawa Islands), whereas "drier" and various rainy seasons (boreal winter, summer, and non rainy season) are observed around Sulawesi and Maluku Islands in the eastern IMC (e.g., Hamada et al. 2002; Mori et al. 2004; Chang et al. 2005). This implies that the eastern IMC may be more sensitive region for droughts by increasing number of consecutive dry days.

Interannual rainfall variability in the IMC has strong relationship with El Niño Southern Oscillation (ENSO) (Hamada et al. 2002, 2012; Hendon 2003; Kubota et al. 2011). Rainfall tends to increase during La Niña years, especially in the eastern part of the IMC during boreal summer and autumn than in winter (Chang et al. 2004). Kubota et al. (2011) described that the eastern IMC experienced drought due to the less rainfall in El Niño years during June to November. In boreal winter, however, this correlation weakens despite persistent El Niño conditions. Many studies have attempted to understand the interannual variability in rainfall amount of the IMC, but that in rainfall extremes and their link to ENSO have not been addressed well. Villafuerte and Matsumoto (2015) examined seasonal variations of the ENSO impacts on heavy rainfall, however the spatial and temporal coverages of the gauge stations were not enough to represent the regional and local differences.

In this study, our main purpose is to investigate how ENSO affects on rainfall extremes over Sulawesi and Maluku islands in the eastern IMC using long-term surface rain gauge data. The influence of ENSO on interannual rainfall variability is greater in the eastern rather than the western IMC (Chang et al. 2004), thus a link between rainfall extreme and ENSO is also expected. The selected region is characterized as drier climate and has various seasonal rainfall variations, besides few studies have been done in this region. Thus, it will be valuable to describe ENSO influences on the heavy rainfall and drought related extremes to understand the regional climate. Localities of seasonal differences of the ENSO impacts in the eastern IMC are another important objective needed to be addressed.

\section{Data and methods}

We collected daily rainfall data at 32 stations in Sulawesi and the Maluku Islands, Indonesia from the Agency for Meteorology Climatology and Geophysics (BMKG) during 1972-2012 (41 years). Data quality controls have been applied to correct the outliers and examine the homogeneity with four statistical tests: the standard normal homogeneity, Buishand range, Pettit, and Von Neumann (Wijngaard et al. 2003). The testing parameters consist of (1) amount of annual rainfall and (2) wet day counting above the threshold of $1.0 \mathrm{~mm}$ day $^{-1}$. Finally, 23 stations (shown in Fig. 


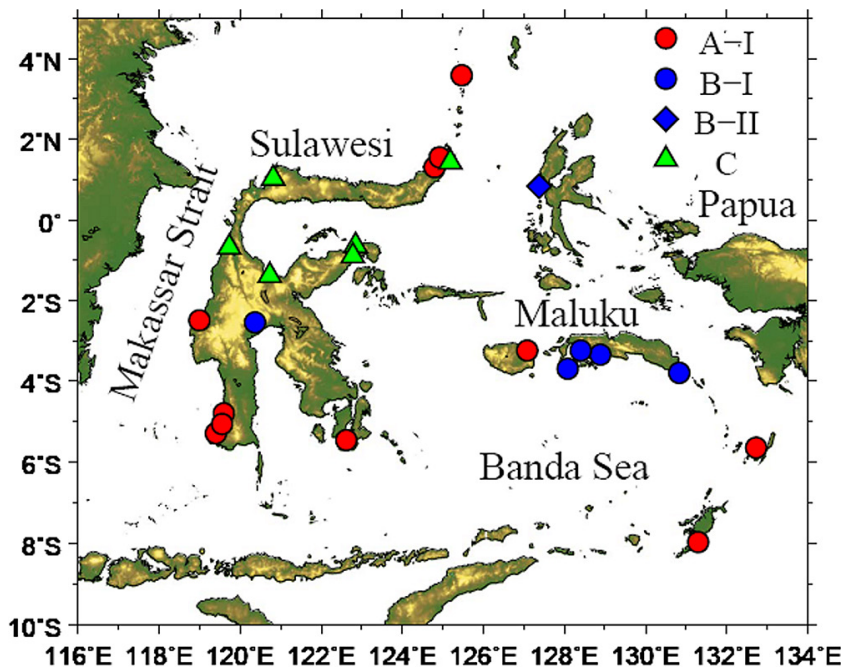

Fig. 1. Rainfall observation sites in Sulawesi and the Maluku Islands. Climatology of seasonal rainfall type is indicated as A-I (red circle), B-I (blue circle), B-II (blue diamond), and C (green triangle) types, respectively. Locations of multiple stations in Manado and Makassar (see Table S1) are a little displaced to avoid overlapping since they are very close each other.

1) are selected which satisfied the following criteria: (1) the data are missing for only five or less days per year, (2) the data are available for 20 or more years, (3) the three of four homogeneity tests on data confirm homogeneity. A year starts on May 1 and ends on April 30 to continuously record the Southern Hemisphere rainy season.

Table 1 summarizes 13 rainfall indices following the definition by Klein Tank et al. (2009). Most indices represent rainfall extreme, although three of them are more indicative of changes in the entire rainfall distributions: PRCPTOT, WDAY, and SDII. A wet day refers to a day with at least $1 \mathrm{~mm}$ of rainfall. The daily rainfall data from the selected 23 stations are used to evaluate rainfall extreme indices and how ENSO relates to these indices. The differences in rainfall extreme indices between El Niño and La Niña years are revealed by composite analysis with the t-test statistical method. Following the Trenberth (1997) definition, the study period (41 years) is classified into 13 El Niño, 16 La Niña, and 12 neutral years. The ENSO year is determined from May 1 until April 30 (same with the year of rainfall dataset) in order to capture the developing and mature phase of ENSO. Hereafter, "year" means a year starting from May 1.

In order to see how the ENSO affects the seasonal and spatial differences of rainfall extreme, we divide the stations into climatological seasonal rainfall types based on the amplitude and phase of smoothed-3-month-running-average of monthly mean rainfall amount. A distinct (no clear) seasonal cycle is defined when the difference between the annual maximum and minimum of monthly mean rainfall amount at a station is $120 \mathrm{~mm} \mathrm{month}^{-1}$ or greater (smaller). The seasonal cycles are classified further into Types I and II implying the presence of either single or multiple monthly peak(s), respectively. Meanwhile, the rainy seasons are divided into Types $\mathrm{A}$ and $\mathrm{B}$ refering to either the maximum rainfall amount occurred in the November-April period or in the May-October period, respectively. The above categories have been resulted in the following five climatological seasonal rainfall types:

A-I: Northern Hemisphere winter rainfall maximum with a single peak

B-I: Northern Hemisphere summer rainfall maximum with a single peak

A-II: Northern Hemisphere winter rainfall maximum with multiple peaks

B-II: Northern Hemisphere summer rainfall maximum with multiple peaks

C: $\quad$ No clear rainy/dry seasons
Table 1. The definition of rainfall indices.

\begin{tabular}{|c|c|c|}
\hline Index & Units & Definitions \\
\hline PRCPTOT & $\mathrm{mm}$ & $\begin{array}{l}\text { Annual total rainfall of wet days } \\
\text { (wet days }=\text { rainfall rate } \geq 1 \mathrm{~mm} \text { ) }\end{array}$ \\
\hline WDAY & days & Number of days with daily rainfall $\geq 1 \mathrm{~mm}$ \\
\hline SDII & $\mathrm{mm}_{\text {day }^{-1}}$ & Average rainfall from wet days \\
\hline $\begin{array}{l}\text { R10mm } \\
\text { R20mm } \\
\text { R50mm } \\
\text { R100mm }\end{array}$ & days & $\begin{array}{l}\text { Number of days per year with rainfall amount } \\
\geq 10 \mathrm{~mm}, \geq 20 \mathrm{~mm}, \geq 50 \mathrm{~mm} \text { and } \geq 100 \mathrm{~mm} \\
\text { respectively }\end{array}$ \\
\hline RX1day & $\mathrm{mm}$ & Annual maximum 1-day rainfall \\
\hline RX5day & $\mathrm{mm}$ & Annual maximum consecutive 5-day rainfall \\
\hline CWD & days & $\begin{array}{l}\text { Annual maximum number of consecutive wet } \\
\text { days }\end{array}$ \\
\hline $\mathrm{CDD}$ & days & $\begin{array}{l}\text { Annual maximum number of consecutive dry } \\
\text { days }\end{array}$ \\
\hline $\begin{array}{l}\text { R95p } \\
\text { R99p }\end{array}$ & $\mathrm{mm}$ & $\begin{array}{l}\text { Rainfall amount per year above a site-specific } \\
\text { threshold value for very and extremely wet days, } \\
\text { calculated as the 95th and 99th percentile of the } \\
\text { distribution of daily rainfall amounts on days } \\
\text { with } 1 \mathrm{~mm} \text { or more rainfall in the } 1981-2010 \\
\text { baseline period. }\end{array}$ \\
\hline
\end{tabular}

Figure 1 shows the spatial distribution of the stations and the climatological seasonal rainfall types. Type A-I is the dominant seasonal rainfall type at 11 stations in Sulawesi and Maluku Islands, whereas the opposite seasonal rainfall Type B-I is found in Sulawesi and the southern area of Maluku with 5 stations. The no clear rainy/dry seasonal Type $\mathrm{C}$ are dispersed among 6 stations in the equatorial Sulawesi. The B-II Type is located in the northern Maluku with only 1 station. However, no station is referred to as A-II Type in this study. Although the analysis periods, data sources, and definitions are different, our results are similar in distributions with seasonal rainfall characteristics in previous studies (e.g., Hamada et al. 2002; Aldrian and Susanto 2003; Chang et al. 2005).

\section{Results and discussions}

\subsection{Interannual variations in rainfall extremes and its linkage to ENSO}

Figure 2 presents the differences in rainfall amount and frequency of rainfall extremes between La Niña and El Niño years. Interannual variations in rainfall extremes are closely related with ENSO phases in a similar manner with rainfall amount described by previous studies (e.g., Hamada et al. 2002; Hendon 2003; Kubota et al. 2011). Most of stations are subject to significant impacts of ENSO on rainfall extremes. The indices corresponding to rainy days (PRCPTOT, WDAY, R10mm, R20mm, and CDD) reveal clear differences with ENSO phases at almost all stations (more than 90\%), with wetter (drier) conditions prevailing in La Niña (El Niño) years. The indices related to heavy rainfall including R50mm, R100mm, RX5day, R95p, and R99p also vary with ENSO, even though the number of stations is less (below $60 \%$ of the stations, except for R95p and R $50 \mathrm{~mm}$ ). The frequency and relative proportion of total rainfall amount from heavy rainfall are greater during La Niña than El Niño years. On the other hand, the heavier rainfall extreme indices such as R100mm and R99p (and also Rx5day and Rx1day) tend to be less affected by ENSO phases (less than 30\%) than R50mm and R95p (around 60\%) and the others of moderate rainfall indices (more than $90 \%$ for $\mathrm{R} 10 \mathrm{~mm}$ and R20mm).

Figure 3 illustrates the spatial distribution of differences 


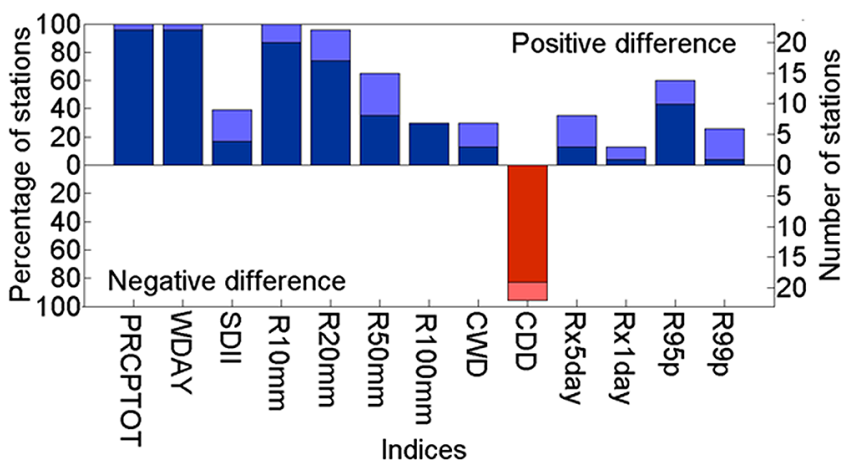

Fig. 2. Percentage of stations with statistically significant differences between La Niña and El Niño years (La Niña minus El Niño) for rainfall indices in Sulawesi and Maluku. Dark blue or dark red, and cyan or magenta indicate positive or negative difference at the $99 \%$ and $95 \%$ confidence levels, respectively.

between ENSO phases and the rainfall extreme indices related to rainy days and heavy rainfall (WDAY and R50mm). Whereas differences with ENSO phases are observed throughout the entire region of Sulawesi and the Maluku Islands, larger differences of WDAY are found at Ternate (82 days, B-II type station) and Ambon/Kairatu (81 days, B-I type station) in Maluku Islands. This means that dry (no rainy) days tend to increase almost 3 months in the El Niño years than La Niña years. The CDD differences also increased in El Niño years at Ternate and Ambon for 20 days and 32 days, respectively (not shown), thus serious droughts may be induced over the region. Besides, the larger differences of R50mm are found at Ambon/Pattimura (14 days, B-I type station) in the southeast Maluku and Makassar/Paotere (11 days, A-I type station) in the south Sulawesi. Other rainfall indices including PRCPTOT, R20mm, RX1day, RX5day, and SDII also have the larger differences with ENSO phases in the area around Southeastern part of Maluku (not shown).

\subsection{Seasonal and spatial differences of ENSO influences on rainfall extremes}

Seasonal variations of ENSO influence on rainfall amount, wet days, and heavy rainfall frequency are also investigated (Fig. 4). Almost all months except in the Northern Hemisphere winter for PRCPTOT (January in Poso) and R50mm (February in Tual), positive differences of PRCPTOT, WDAY, and R50mm in La Niña years are found at all stations. In general, the PRCPTOT and WDAY are significantly different between El Niño and La Niña years during July-November with a peak in October in Maluku and Sulawesi Islands, whereas their differences are small during December-February. These results are consistent with larger influence of ENSO to the interannual rainfall variability in the Northern Hemisphere summer and autumn described in the previous studies (e.g., Hendon 2003; Kubota et al. 2011).

Figure 4 also depicts the ENSO influences on the indices for each climatological seasonal rainfall type. As for R50mm, the larger differences appear in November (Type A-I), August (Type B-I), and July (Type C). These peaks do not appear in the middle of rainy season, but in transitional seasons of the wet and dry months for each seasonal rainfall type. Thus, the influences of ENSO on heavy rainfall frequency are more dominant in transitional seasons than in the middle of rainy season. However, the PRCPTOT and WDAY peaks occur in July-November for all seasonal rainfall types, whereas a second peak also exists in December-February for Type $\mathrm{C}$ stations. This implies a shift in the rainy season onset and withdrawal with ENSO phases (Hamada et al. 2002) and/or changes of atmospheric stability that may induce significant differences in heavy rainfall frequency during transitional seasons.
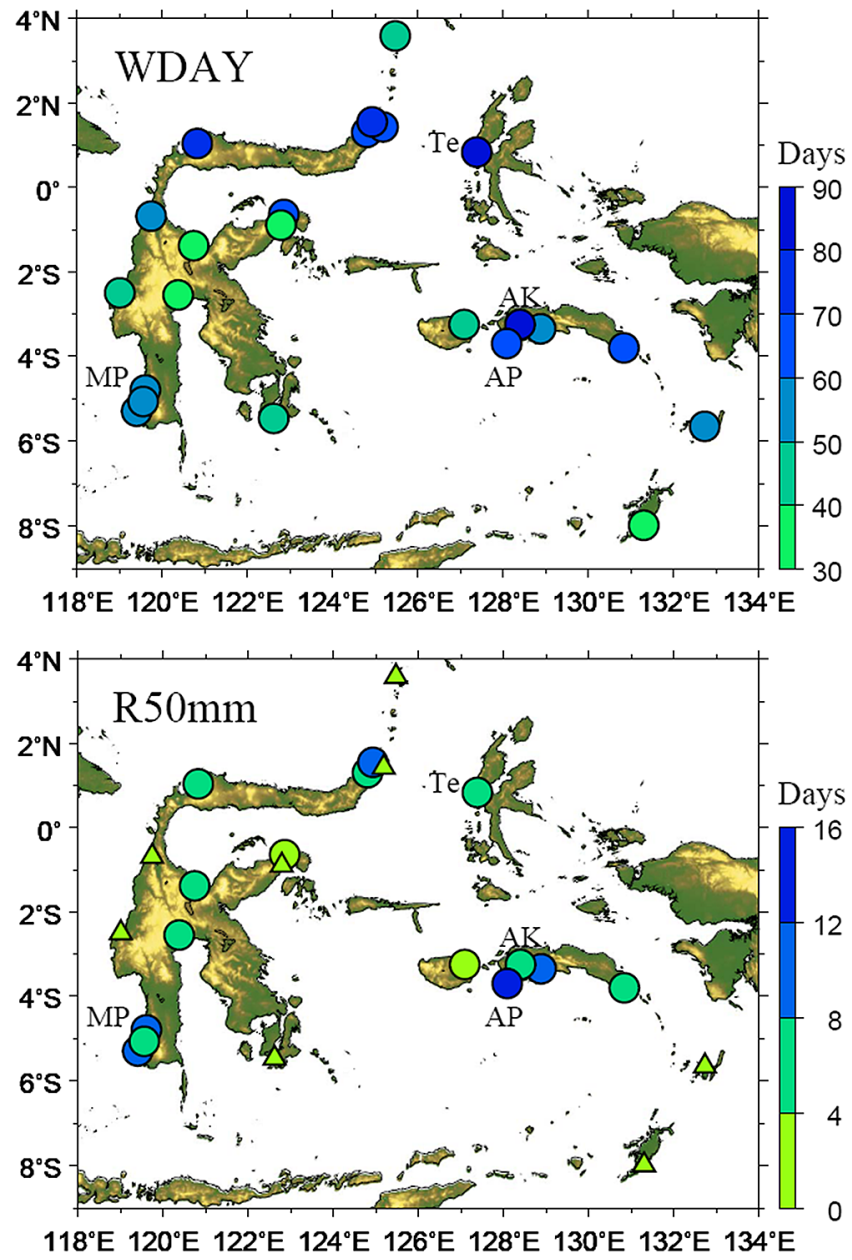

Fig. 3. Composite differences in La Niña minus El Niño years for WDAY and $\mathrm{R} 50 \mathrm{~mm}$. All the stations show positive anomalies in La Niña years. Circles (triangles) indicate a statistically significant (insignificant) difference at the $95 \%$ confidence level. The abbreviations on the figures indicate stations name: Te (Ternate), AK (Ambon/Kairatu), AP (Ambon/Pattimura) and MP (Makassar/Paotere).

\subsection{Discussions on a link between air-sea interaction and rain- fall extremes}

Kubota et al. (2011) suggested that an intensification of seasonal southerly wind reduced sea surface temperature (SST) in the eastern IMC and suppressed convection during July-November in El Niño years. In addition, shallow thermal convection produces subsidence over the Banda Sea in the pre-Australian monsoon season and extremely dry conditions spread through the surrounding region in October during El Niño years. Meanwhile, the warmer SST and wetter conditions prolong during La Niña years. Also, warmer sea surface water will be more transported from the Pacific to the Banda Sea through the Makassar Strait with what so called as the Indonesian Throughflow in La Niña years and less transported in El Niño years (e.g., Gordon and Fine 1996; Wijffels and Meyers 2004). This suggests that local SST variations surrounding the eastern IMC associated with an influence of Walker (zonal) circulation as controlling factors of rainfall amount and rainfall extremes.

From the trend analysis of Villafuerte and Matsumoto (2015), the results presume wetter tendencies in the eastern and drier trends in the western IMCs. This suggests that the ENSO effects on the interannual variations in rainfall extremes are weaker in the western IMC, because it is associated with the Asian winter monsoon, which is the more dominant factor in this region (Aldrian and Djamil 2008; Hamada et al. 2012). The Indonesian Throughflow may play important roles in the interannual variations of 

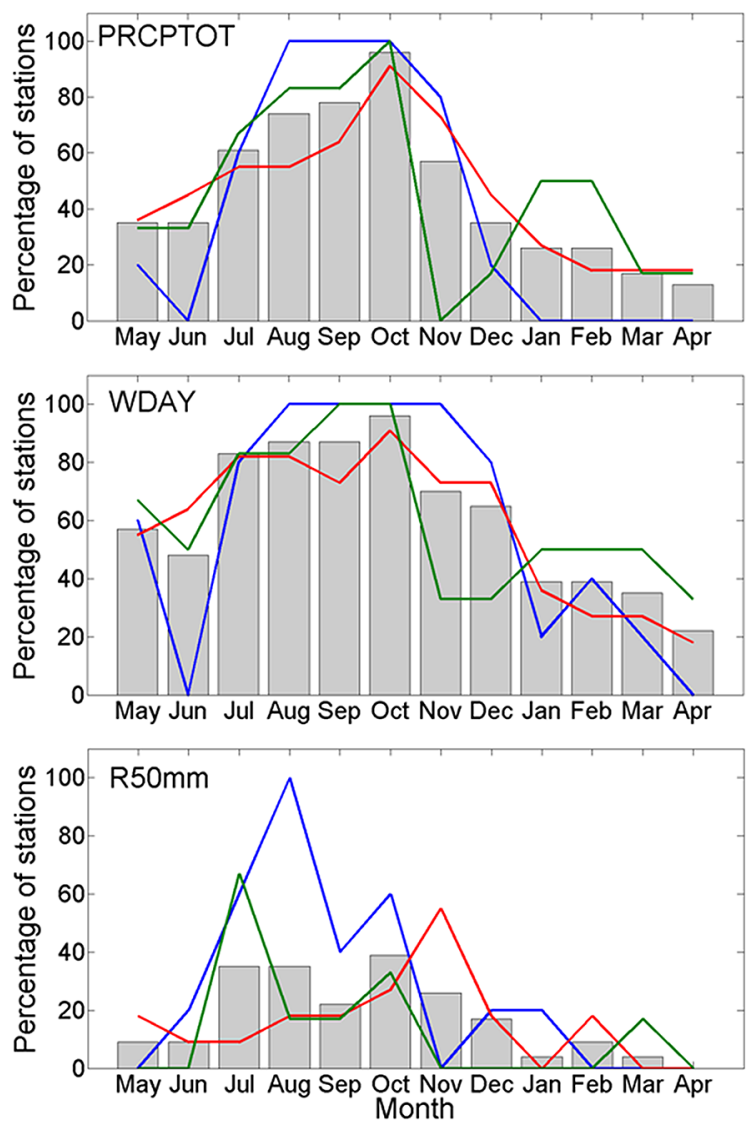

Fig. 4. Percentage of stations with statistically significant differences between La Niña and El Niño years for PRCPTOT, WDAY, and R50mm at the $95 \%$ confidence level. The bars, red lines, blue lines, and green lines indicate all, A-I, B-I, and C types stations, respectively. Only positive differences are shown in this figure. Detail explanation of the limited negative differences are described in the main text.

ENSO and the Asian monsoon. It could bring a freshwater surface layer from the western IMC, then inhibit warm surface water from the Pacific flowing southward to the Indian Ocean, and cause a cooler Indian Ocean that may weaken the Asian monsoon (Wajsowicz 2002). This would be a different set of dynamics than what occurs in the eastern IMC as determined by this study.

\section{Conclusions}

We have explored how interannual variability related to ENSO influences and their spatioseasonal linkages on rainfall extremes over Sulawesi and the Maluku Islands in the eastern IMC during 1972-2012 using highly spatially distributed surface daily rainfall data that have never been done by previous studies in the region. The results conclude that interannual variations of rainfall extremes are correlated strongly with ENSO phases. Wetter (drier) conditions are associated with La Niña (El Niño) events, especially for rainfall indices related to wet days such as PRCPTOT, WDAY, R10mm, R20mm, and CDD at almost all stations (more than $90 \%$ ). Heavy rainfall indices such as R50mm, and R95p, also increase during La Niña years at more than $60 \%$ of the stations, whereas the indices for severest rainfall such as R100mm and R95p tend to be less affected (less than 30\%). Thus, ENSO influences are more dominant for the frequency of moderately intense rainfall than severest rainfall.

Seasonal and spatial differences of ENSO influences on rainfall amount, wet days, and frequency of heavy rainfall are identified in this study. ENSO influences are predominant during July-November on rainfall amount and wet days, whereas its impacts are less in December-February. On the other hand, differences in the frequency of heavy rainfall are more evident in transitional seasons for the stations whose rainfall types are classified as Types A-I (the whole region of Maluku/Sulawesi), B-I (southern Maluku), and C (equatorial Sulawesi). It is infered that ENSO affetcs the timing of rainy season onset over the region as mentioned by Hamada et al. (2002), but further analysis on this topic is beyond our study. It is required further study to examine the relationship between heavy rainfall frequency and rainy season onset.

Preferable environmental conditions and generation mechanisms for inducing rainfall extreme events over the IMC is another subject for future study. Wu et al. (2013) indicated the importance of the interaction between local circulation (land-sea breeze) and large-scale circulation due to Madden-Julian Oscillation (MJO) for inducing prolonged convection in Jakarta heavy rainfall event in January 2013. Hidayat and Kizu (2010) suggested that MJO controls a considerable fraction of the total precipitation in Indonesia (10-30\% of climatological mean over land, whereas 60-70\% over the seas) and excess rainfall occurs during the active phase of MJO over the IMC. Kubota et al. (2011) proposed that eastward propagation of the MJO convection tends to be suppressed by the cooler SST surrounding the eastern IMC in El Niño years. However, interannual SST variations over the IMC and their influences on MJO activities have not been examined well. Thus, investigation of the frequency of heavy rainfall events that coincide with the MJO phases and their interannual changes due to ENSO phases are emerging needs.

\section{Acknowledgements}

This research is supported by the Science and Technology Research Partnership for Sustainable Development-Maritime Continent COE (SATREPS-MCCOE) JST/JICA program, Grant-inAid of No. 15K01167 and No. 26220202 from the Japan Society for the Promotion of Science (JSPS), Grant-in-Aid for Research on Priority Areas from Tokyo Metropolitan University, and Green Network of Excellence (GRENE) from the Japanese Ministry of Education, Culture, Sports, Science and Technology. We thank $\mathrm{BPPT}$ and $\mathrm{BMKG}$ as the main responsible agencies of the project for the continuing supports.

Edited by: Y. Kosaka

\section{Supplement}

Table S1 describes station information on the location, available data period, and seasonal rainfall types around Sulawesi and Maluku Islands in Indonesia.

\section{References}

Alexander, L. V., X. Zhang, T. C. Peterson, J. Caesar, B. Gleason, A. M. G. Klein Tank, M. Haylock, D. Collins, B. Trewin, F. Rahimzadeh, A. Tagipour, K. Rupa Kumar, J. Revadekar, G. Griffiths, L. Vincent, D. B. Stephenson, J. Burn, E. Aguilar, M. Brunet, M. Taylor, M. New, P. Zhai, M. Rusticucci, and J. L. Vazquez-Aguirre, 2006: Global observed changes in daily climate extremes of temperature and precipitation. $J$. Geophys. Res., 111, D5109, doi:10.1029/2005JD006290.

Aldrian, E., and R. D. Susanto, 2003: Identification of three dominant rainfall regions within Indonesia and their relationship to sea surface temperature. Int. J. Climatol, 23, 1435-1452.

Aldrian, E., and Y. S. Djamil, 2008: Spatio-temporal climatic change of rainfall in East Java Indonesia. Int. J. Climatol, 28, 435-448.

Chang, C.-P., Z. Wang, J. Ju, and T. Li, 2004: On the relationship between western maritime continent monsoon rainfall and ENSO during northern winter. J. Climate, 17, 665-672. 
Chang, C.-P., Z. Wang, J. McBride, and C.-H. Liu, 2005: Annual cycle of Southeast Asia-maritime continent rainfall and the asymmetric monsoon transition. J. Climate, 18, 287-301.

Easterling, D. R., J. L. Evans, P. Ya. Groisman, T. R. Karl, K. E. Kunkel, and P. Ambenje, 2000: Observed variability and trends in extreme climate events: A brief review. Bull. Amer. Meteor. Soc., 81, 417-425.

Endo, N., J. Matsumoto, and T. Lwin, 2009: Trends in precipitation extremes over Southeast Asia. SOLA, 5, 168-171.

Frich, P., L. V. Alexander, P. Della-Marta, B. Gleason, M. Haylock, A. M. G. Klein Tank, and T. Peterson, 2002: Observed coherent changes in climatic extremes during the second half of twentieth century. Climate Res., 19, 193-212.

Gordon, A. L., and Fine, R. A., 1996: Pathways of water between the Pacific and Indian oceans in the Indonesian seas. Nature, 379, 146-149.

Hamada, J.-I., M. D. Yamanaka, J. Matsumoto, S. Fukao, P. A. Winarso, and T. Sribimawati, 2002: Spatial and temporal variations of the rainy season over Indonesia and their link to ENSO. J. Meteor. Soc. Japan, 80, 285-310.

Hamada, J.-I., S. Mori, H. Kubota, M. D. Yamanaka, U. Haryoko, S. Lestari, R. Sulistyowati, and F. Syamsudin, 2012: Interannual rainfall variability over northwestern Jawa and its relation to the Indian Ocean Dipole and El Niño-Southern Oscillation events. SOLA, 8, 69-72.

Hendon, H. H., 2003: Indonesian rainfall variability: Impacts of ENSO and local air-sea interaction. J. Climate, 16, 17751790.

Hidayat, R., and S. Kizu, 2010: Influence of the Madden-Julian Oscillation on Indonesian rainfall variability in austral summer. Int. J. Climatol., 30, 1816-1825.

Klein Tank, A. M. G., F. W. Zwiers, and X. Zhang, 2009: Guidelines on analysis of extremes in a changing climate in support of informed decisions for adaptation. Climate Data and Monitoring WCDMP-No.72, WMO-TD, 1500, 56pp.

Kubota, H., R. Shirooka, J.-I. Hamada, and F. Syamsudin, 2011: Interannual rainfall variability over the eastern maritime continent. J. Meteor. Soc. Japan, 89A, 111-122.

Mori, S., J.-I. Hamada, Y. I. Tauhid, M. D. Yamanaka, N. Okamoto, F. Murata, N. Sakurai, H. Hashiguchi, and T. Sribimawati, 2004: Diurnal land-sea rainfall peak migration over Sumatera Island, Indonesian maritime continent, observed by TRMM satellite and intensive rawinsonde soundings. Mon. Wea. Rev., 132, 2021-2039.

Ramage, C. S., 1968: Role of a tropical "maritime continent" in the atmospheric circulation. Mon. Wea. Rev., 96, 365-370.

Trenberth, K. E., 1997: The definition of El Niño. Bull. Amer. Meteor. Soc., 78, 2771-2777.

Villafuerte, M. Q., and J. Matsumoto, 2015: Significant influences of global mean temperature and ENSO on extreme rainfall in Southeast Asia. J. Climate, 28, 1905-1919.

Wajsowicz, R. C., 2002: Air-sea interaction over the Indian Ocean due to variations in the Indonesian throughflow. Climate Dyn., 18, 437-453.

Wijffels, S., and G. Meyers, 2004: An intersection of oceanic waveguides: Variability in the Indonesian Throughflow region. J. Phys. Oceanogr., 34, 1232-1253.

Wijngaard, J. B., A. M. G. Klein Tank, and G. P. Können, 2003: Homogeneity of 20th century European daily temperature and precipitation series. Int. J. Climatol., 23, 679-692.

Wu, P., A. A. Arbain, S. Mori, J.-I. Hamada, M. Hattori, F. Syamsudin, and M. D. Yamanaka, 2013: The effects of an active phase of the Madden-Julian Oscillation on the extreme precipitation event over western Java Island in January 2013. SOLA, 9, 79-83.

Yatagai, A., K. Kamiguchi, O. Arakawa, A. Hamada, N. Yasutomi, and A. Kitoh, 2012: APHRODITE: Constructing a longterm daily gridded precipitation dataset for Asia based on a dense network of rain gauges. Bull. Amer. Meteor. Soc., 93, 1401-1415.

Manuscript received 15 November 2015, accepted 11 January 2016 SOLA: https://www.jstage.jst.go.jp/browse/solal 